\title{
Aplikasi Try-On Hairstyle Berbasis Augmented Reality
}

\author{
Pinasthika Aulia Fadhila ${ }^{1}$, Ledya Novamizanti ${ }^{2}$, Fat'hah Noor Prawita ${ }^{3}$ \\ 1,2Program Studi S1 Teknik Telekomunikasi, \\ Fakultas Teknik Elektro, \\ Universitas Telkom, Bandung \\ ${ }^{1}$ pinasthikauliaf@student.telkomuniversity.ac.id, 2ledyaldn@telkomuniversity.ac.id \\ 3Program Studi D3 Rekayasa Perangkat Lunak Aplikasi, \\ Fakultas Ilmu Terapan, \\ Universitas Telkom, Bandung \\ fathah@tass.telkomuniversity.ac.id
}

\begin{abstract}
Abstrak
Teknologi augmented reality mempermudah hidup manusia dan dapat diaplikasikan di berbagai macam bidang seperti pengelola jasa pangkas rambut. Ketidakpastian pemilihan model rambut oleh pelanggan membuat penata rambut dan pelanggan menjadi ragu. TryOn Hairstyle merupakan aplikasi berbasis Android yang dapat memberikan gambaran secara virtual berbagai jenis model rambut pria maupun wanita, dan sesuai dengan bentuk wajah pengguna. Aplikasi ini menerapkan algoritma Viola-Jones untuk tahap face detection dan Face Tracking secara markerless. Setelah melakukan deteksi wajah, sistem akan mengkategorikan wajah pelanggan berdasarkan bentuk wajah dan aplikasi ini akan menampilkan berbagai model rambut yang tersedia berdasarkan bentuk wajah pelanggan dengan teknologi augmented reality. Sistem ini diuji dengan pengujian Black Box, pengujian berdasarkan jarak, pengujian berdasarkan intensitas cahaya, pengujian berdasarkan rotasi kepala, dan pengujian user acceptance. Hasil dari aplikasi ini adalah dapat mendeteksi wajah dan menampilkan model rambut yang sesuai dengan akurasi $100 \%$ dengan jarak terbaik pada $30 \mathrm{~cm}-40 \mathrm{~cm}$, sudut wajah terhadap kamera sebesar $0^{\circ}$, dan cahaya dengan intensitas cahaya lebih besar dari 10 lux. Tingkat kepuasan pelanggan dalam menggunakan aplikasi ini sebesar $91,7625 \%$.
\end{abstract}

Kata kunci: Android, augmented reality, face detection, model rambut, Viola-Jones

\begin{abstract}
Augmented Reality technology simplifies human life and can be applied in various fields such as barber services. Uncertainty about the choice of hairstyles by customers makes hairstylists and customers confused. Try-On Hairstyle is an android-based application that can provide a virtual picture of various types of male and female hair models, and matches the user's face shape. This application applies the Viola-Jones algorithm for the face detection and face tracking stages in a markerless manner. After doing face detection stage, the system categorizes the customer's face based on the face shape, and then the application displays various hair models available based on the customer's face shape using augmented reality technology. This system was tested by Black Box testing, testing based on distance, testing based on the light intensity, testing based on head rotation, and user acceptance
\end{abstract}


testing. The results of this application can detect faces and display hair models that match $100 \%$ of accuracy with the best distance at $30-40 \mathrm{~cm}$, face angle to the camera by $0^{\circ}$, and light intensity above 10 lux. The level of customer satisfaction in using this application is $91.7625 \%$

Keywords: Android, augmented reality, face detection, hairstyle, Viola-Jones

\section{Pendahuluan}

Tatanan rambut merupakan sebuah kebutuhan bagi para pria maupun wanita untuk penampilan yang lebih maksimal. Pemilihan model rambut yang tidak sesuai akan menghasilkan penampilan yang kurang bagus. Augmented Reality (AR) dapat didefinisikan sebagai sistem di mana dunia nyata dan virtual telah digabungkan dan dilakukan secara real time [1]. Defenisi lain, AR adalah teknologi di antara realitas nyata dan realitas virtual. Saat ini, teknologi sudah diterapkan di berbagai bidang, seperti di bidang pendidikan untuk mendukung pembelajaran di sekolah [2], sebagai katalog rumah secara digital [3], sebagai media untuk promosi properti [4], dan lain-lain. Salah satu contoh pengaplikasian lain teknologi AR adalah dapat menampilkan berbagai pilihan model rambut secara virtual. Teknologi AR membantu pelanggan dalam memilihkan model rambut yang sesuai dengan bentuk wajah mereka. Penyedia jasa pangkas rambut hanya perlu menyiapkan perangkat telpon pintar berbasis Android, yang mendukung teknologi AR dan pelanggan dapat memilih dan mencoba model rambut yang direkomendasikan berdasarkan bentuk wajah pelanggan secara virtual sebelum proses pemangkasan rambut dilaksanakan. Penelitian yang dihasilkan oleh [5] menggunakan webcam sebagai media untuk pengambilan foto pengguna dan menggunakan komputer sebagai media untuk mengolah hasil penggabungan antara foto dan model rambut. Peneliti [6] mengajukan aplikasi model tatanan rambut untuk pria berbasis Android. Namun, aplikasi yang dirancang masih memperlukan brosur sebagai marker. Kelemahan dari hasil perancangan aplikasi pada penelitian [6] adalah tidak bisa dicoba secara virtual dan real time oleh pelanggan.

Penelitian ini dirancang sebuah aplikasi Try-On Hairstyle, yang dapat mendeteksi wajah pengguna yang kemudian dapat mengkategorikan bentuk wajah dan memberikan rekomendasi model rambut sesuai bentuk wajah. Aplikasi ini berbasis Android dan dapat digunakan oleh pengguna pria maupun pengguna wanita. Dasar dari penelitian ini adalah pendeteksian bentuk wajah menggunakan metode Viola-Jones yang diterapkan pada library OpenCV dan tambahan library dlib serta rekomendasi model rambut yang ditampilkan menggunakan teknologi AR berbentuk objek 3D. Penggabungan antara metode Viola-Jones dan teknologi AR dapat dimanfaatkan untuk pembuatan aplikasi yang bisa dimanfaatkan dalam kehidupan sehari-hari, contohnya adalah digunakan pada jasa pangkas rambut.

\section{Metodologi Penelitian}

\subsection{Klasifikasi Bentuk Wajah dan Hairstyle Setiap Bentuk Wajah}

Bentuk wajah manusia bisa diklasifikasikan menjadi 7 jenis untuk bentuk wajah, yaitu: oval, round, square, oblong, diamond, inverted triangle, dan heart-shape [7]. Bentuk wajah diilustrasikan pada Gambar 1 (a) untuk bentuk wajah pria [7] dan pada Gambar 1 (b) untuk bentuk wajah wanita [8]. 


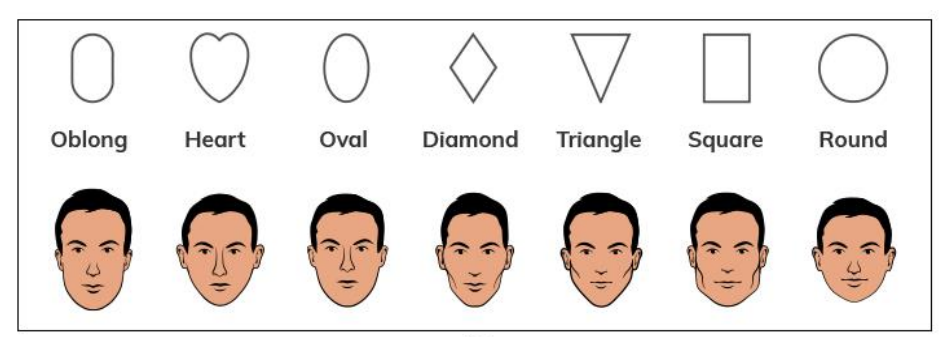

(a)

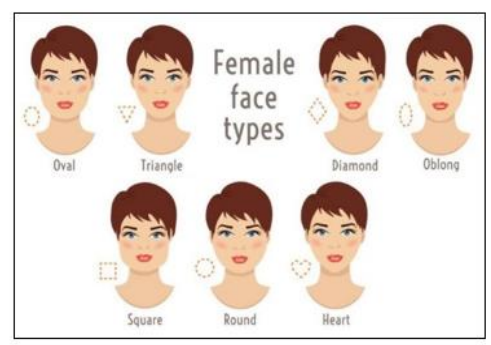

(b)

Gambar 1. Klasifikasi bentuk wajah (a) pria, (b) wanita

Setiap bentuk wajah tersebut dapat diidentifikasi dengan beberapa syarat sebagai berikut [7].

1. Oval-shaped face: Ukuran panjang wajah adalah ukuran yang paling panjang di antara ukuran lainnya. Ukuran lebar dahi dan lebar tulang pipi kurang lebih sama tetapi masih lebih besar daripada ukuran panjang rahang.

2. Round-shaped face: Panjang wajah dan panjang tulang pipi kurang lebih sama tetapi lebih besar daripada lebar dahi dan panjang rahang yang ukurannya kurang lebih sama.

3. Square-shaped face: Ukuran keseluruhan fitur, yaitu panjang wajah, lebar dahi, lebar tulang pipi, dan panjang rahang, memiliki ukuran yang kurang lebih sama.

4. Oblong-shaped face: Ukuran panjang wajah memiliki nilai yang paling besar di antara fitur lain, yaitu lebar dahi, lebar tulang pipi, dan panjang rahang, yang memiliki panjang kurang lebih sama.

5. Diamond-shaped face: Ukuran panjang wajah adalah ukuran yang paling besar di antara ukuran yang lain, dengan ukuran panjang rahang yang memiliki ukuran paling kecil dan ukuran lebar pipi lebih kecil dari panjang wajah tetapi lebih besar dibandingkan dengan lebar dahi.

6. Triangle-shaped face: Ukuran panjang rahang merupakan ukuran paling besar di antara yang lain, dengan ukuran lebar dahi yang memiliki ukuran paling kecil. Ukuran lebar tulang pipi lebih kecil daripada panjang rahang dan lebih besar daripada lebar dahi.

7. Heart-shaped face: Ukuran lebar dahi merupakan ukuran paling besar di antara yang lain, dengan ukuran panjang rahang yang memiliki ukuran paling kecil. Ukuran lebar tulang pipi lebih kecil daripada lebar dahi dan lebih besar daripada panjang rahang.

Beberapa tahap yang harus dilakukan untuk menentukan model rambut yang cocok dengan bentuk wajah, yaitu: (1) ukur wajah; (2) identifikasi bentuk wajah yang dimiliki; dan (3) tentukan model rambut yang cocok untuk setiap bentuk wajah. 


\subsection{Augmented Reality (AR)}

AR merupakan suatu tampilan dari sudut pandang pengguna dari dunia nyata yang bersifat real-time dengan menggabungkan objek nyata dan virtual menjadi 3D [1]. Teknologi AR ini sangat berguna untuk mempermudah penggunanya untuk mengetahui keadaan sekitar secara virtual yang sedemikian rupa dibuat mirip seperti keadaan pada dunia nyata. Menurut Ronald T Azuma, ada tiga karakteristik yang harus dipenuhi oleh suatu teknologi AR, yaitu [2]: terdapat proses penggabungan antara dunia nyata dan virtual, interaktif secara real-time, dan disajikan dalam 3D. Berdasarkan cara pendeteksiannya, AR dibagi menjadi dua metode, yaitu markerless tracking dan markerbased tracking. Sesuai dengan namanya, metode marker-based tracking membutuhkan suatu marker atau penanda sebagai penentunya, biasa juga dikenal sebagai image recognition [1]. Hasil dari metode marker-based tracking adalah objek 3D yang menempel pada marker yang digunakan sebagai penentu. Metode markerless tracking menggunakan algoritma tertentu sebagai penentunya dan algoritma hanya perlu mengidentifikasi pola, warna, dan fitur lainnya untuk memberikan hasil [1].

\subsection{Face Detection dan Face Tracking}

Face detection atau deteksi wajah merupakan proses identifikasi manusia berdasarkan wajah menggunakan kamera secara otomatis dengan melihat wajah yang ada di suatu gambar dibantu dengan sistem komputer yang ada [9]. Face tracking merupakan suatu cara untuk mengidentifikasi dan memverifikasi wajah dari suatu gambar dengan mengenali posisi mata, mulut, dan hidung manusia, serta mengabaikan objek lain yang tidak menyerupai wajah manusia [10].

\subsection{Object Detection Viola-Jones}

Viola-Jones merupakan suatu metode yang bertujuan untuk mendeteksi suatu objek. Metode tersebut diusulkan pertama kali pada tahun 2001 oleh Paul Viola dan Michael Jones. Metode Viola Jones merupakan salah satu metode deteksi wajah yang memiliki tingkat akurasi tinggi dan komputasi cepat [11]. Gambar 2 menunjukkan tahapan utama metode Viola-Jones [12].

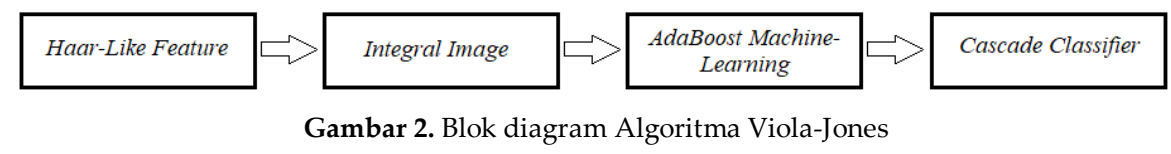

Tahap pertama, Haar-Like Feature memproses gambar dalam bentuk kotak-kotak, di mana dalam satu kotak terdapat beberapa pixel. Pada tampilan tersebut, diperoleh perbedaan nilai (threshold) yang menandakan daerah gelap dan terang. Kemudian, integral image menentukan ada atau tidaknya fitur Haar pada sebuah gambar dan pada skala yang berbeda. Selanjutnya, algoritma AdaBoost melakukan pemilihan fitur dalam jumlah banyak dengan hanya memilih fitur tertentu [12]. Evaluasi setiap fitur dilakukan terhadap data latih dengan menggunakan nilai dari fitur tersebut. Fitur terbaik, yaitu fitur yang memiliki batasan terbesar antara objek dan non-objek. Tahap terakhir, Cascade classification mengkombinasikan classifier yang kompleks dalam sebuah struktur bertingkat, sehingga dapat meningkatkan kecepatan pendeteksian obyek dengan memfokuskan pada daerah citra yang berpeluang [12]. 


\section{Pembahasan}

\subsection{Spesifikasi Sistem dan Skema Proses}

Spesifikasi sistem yang dibangun adalah suatu program yang melatih suatu sistem sehingga dapat dapat mendeteksi suatu citra wajah pada tubuh manusia menggunakan metode Viola-Jones. Dalam membangun sistem ini, digunakan Open Source Computer Vision Library (OpenCV) dan Microsoft Visual Studio 2019. OpenCV telah mempunyai banyak fitur, antara lain: pengenalan wajah, deteksi wajah, pelacakan wajah, dan berbagai jenis metode Artificial Intellegence (AI) [13]. Microsoft Visual Studio merupakan perangkat lunak yang dapat digunakan untuk mengembangkan suatu aplikasi, salah satunya adalah aplikasi berbentuk console. Gambar 3 merupakan skema proses dari aplikasi Try-On Hairstyle.

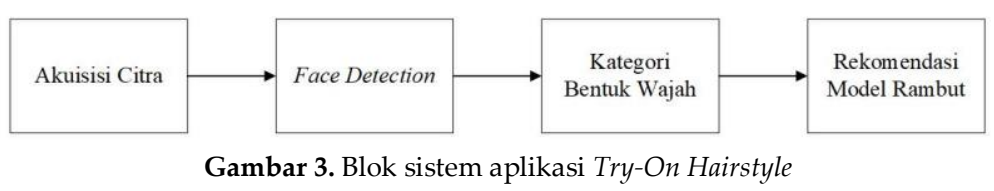

Tahap pertama yang dilakukan oleh sistem adalah melakukan akuisisi citra menggunakan kamera smartphone. Setelah dilakukan akuisisi citra dan didapatkan citra digital, sistem melakukan face detection menggunakan algoritma Viola-Jones dan ditentukan juga kategori bentuk wajah pengguna secara bersamaan. Setelah didapatkan hasil dari kategori bentuk wajah pengguna, sistem menampilkan rekomendasi model rambut sesuai dengan gender pengguna, pria atau wanita. Gambar 4 mengilustrasikan tahapan-tahapan utama dari algoritma Viola-Jones [14].

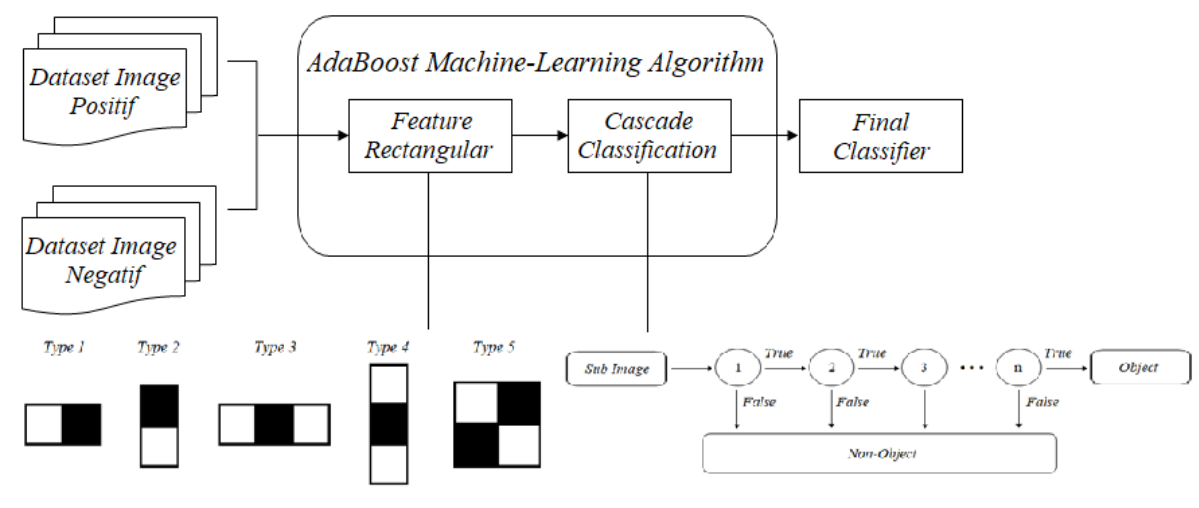

Gambar 4. Framework dasar Algoritma Viola-Jones

Berdasarkan Gambar 4, proses Viola-Jones dimulai dari tahapan training. Pada tahapan training, dibutuhkan data citra pelatihan positif dan negatif dengan ukuran $24 \times 24$ pixel. Maksud data positif yaitu sampel dari citra wajah dengan posisi lurus menghadap ke depan. Sedangkan untuk data pelatihan negatif yaitu sampel dari citra non wajah. Setelah tahapan pelatihan ini selesai, diperoleh nilai akhir berupa data statistik hasil training. Nilai akhir inilah yang menentukan apakah nantinya citra yang dideteksi tersebut terdapat citra wajah atau tidak. Setelah dilakukan face detection menggunakan algoritma Viola-Jones, selanjutnya proses pengkategorian bentuk wajah. Pengkategorian bentuk wajah didasari oleh jarak dlib point dan ukuran rectangle yang dihasilkan pada saat pendeteksian wajah. Dlib point yang digunakan adalah point 0 dan point 16 untuk jarak lebar dahi, point 1 dan point 15 untuk jarak lebar tulang pipi, serta point 8 dan point 14 untuk panjang rahang, dengan tambahan panjang sumbu $\mathrm{x}$ rectangle 
untuk panjang wajah. Gambar 5 menampilkan diagram alir untuk penentuan kategori bentuk wajah.

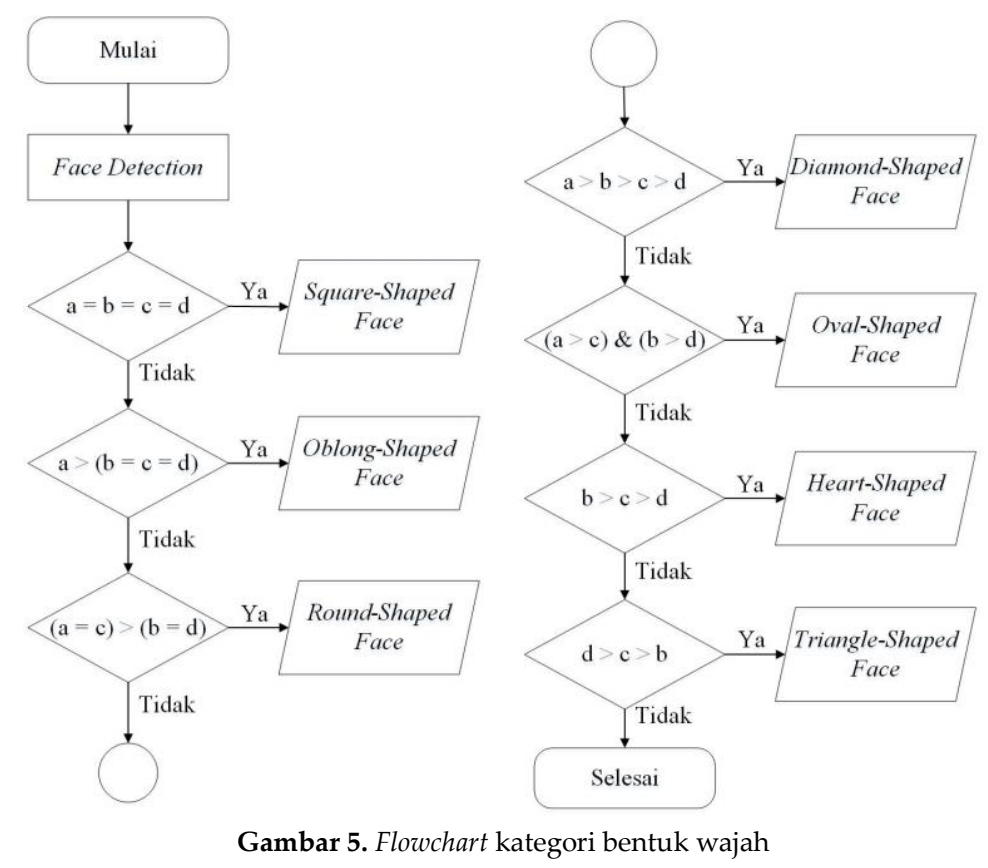

Pada Gambar 5, terdapat 4 variabel penentu bentuk wajah, yaitu variabel $a$ untuk panjang wajah, variabel $b$ untuk lebar dahi, variabel $c$ untuk lebar tulang pipi, dan variabel $d$ untuk panjang rahang. Dari hasil pengkategorian bentuk wajah, system menampilkan rekomendasi model rambut sesuai dengan bentuk wajah yang terbaca oleh sistem dan sesuai dengan gender yang dipilih oleh pengguna. Apabila pengguna memilih gender pria, rekomendasi model rambut yang ditampilkan oleh sistem adalah rekomendasi model rambut untuk pria sesuai dengan bentuk wajah yang terdeteksi. Apabila pengguna memilih gender wanita, rekomendasi model rambut yang ditampilkan oleh sistem adalah rekomendasi model rambut untuk wanita sesuai dengan bentuk wajah yang terdeteksi.

\subsection{Use-Case Diagram}

Use-Case Diagram menyatakan visualisasi interaksi yang terjadi antara pengguna (aktor) dengan sistem [15]. Use-Case Diagram merupakan gambaran yang menjelaskan konteks dari sebuah sistem sehingga terlihat jelas batasan dari sistem. Terdapat 2 elemen penting yang harus digambarkan, yaitu aktor dan use-case. Aktor merupakan segala sesuatu yang berinteraksi langsung dengan sistem. Aktor dapat berupa orang atau sistem komputer yang lain. Aktor dinotasikan dengan simbol gambar stick-man dengan nama di bagian bawah yang menyatakan peran atau sistem. Use-case dinotasikan dengan simbol elips, dan diberi kata kerja aktif di bagian dalam yang menyatakan aktivitas dari perspektif aktor. Setiap aktor dimungkinkan untuk berinteraksi dengan sistem dalam banyak use-case dan setiap use-case bisa dijalankan oleh lebih dari satu aktor [15]. Gambar 6 menunjukkan Use-Case Diagram untuk aplikasi Try-On Hairstyle. Terdapat aktor atau pengguna dan sistem dari aplikasi Try-On Hairstyle. 


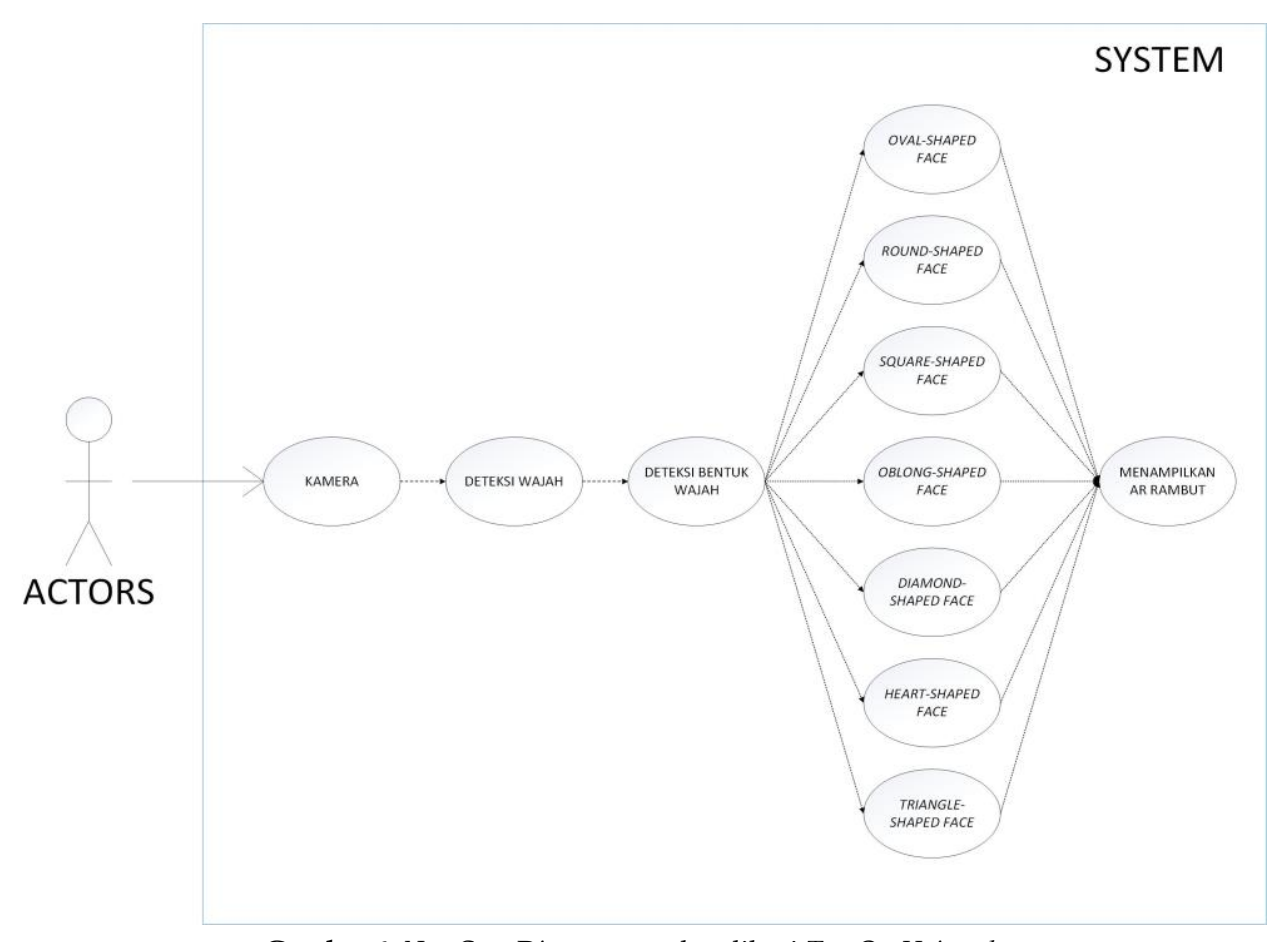

Gambar 6. Use-Case Diagram untuk aplikasi Try-On Hairstyle

\subsection{User Acceptance}

User acceptance merupakan pengujian secara objektif, di mana diuji oleh target pengguna aplikasi secara langsung, yaitu pelanggan jasa pangkas rambut. User acceptance ini dilakukan untuk melihat kesiapan aplikasi yang dirancang berdasarkan pendapat langsung dari target pengguna aplikasi. Pengujian user acceptance dilakukan melalui uji coba langsung, uji perspektif, dan kuisioner.

\subsubsection{Uji Coba Langsung}

Uji coba kepada pengguna secara langsung terhadap aplikasi dilakukan agar dapat mengetahui tingkat kepuasan pengguna terhadap aplikasi tersebut. Parameter yang menjadi patokan untuk uji coba secara langsung adalah tampilan, fungsionalitas, hasil, dan tingkat kepuasan. Parameter tampilan merupakan parameter yang menilai tampilan aplikasi secara keseluruhan. Parameter fungsionalitas merupakan parameter yang menilai fungsi aplikasi secara keseluruhan, baik dari fitur-fitur yang ada maupun dari fungsi utama aplikasi. Performansi aplikasi diuji berdasarkan hasil deteksi wajah, pengkategorian bentuk wajah, dan model rambut yang ditampilkan. Parameter akurasi digunakan untuk menilai ketepatan sistem dalam mendeteksi objek citra. Perhitungan akurasi yaitu total data yang terdeteksi benar dibagi total data keseluruhan [16], [17]. Tingkat kepuasan merupakan parameter yang menilai mengenai kepuasan pengguna secara keseluruhan terhadap aplikasi Try-On Hairstyle. Range nilai untuk setiap parameternya adalah 1 sampai dengan 100. Terdapat empat kategori penilaian, yaitu kurang, cukup, baik, dan sangat baik. Range nilai yang diberikan untuk kategori kurang, adalah 1-25. Range nilai untuk kategori cukup, adalah 26-50. Range nilai yang diberikan untuk kategori baik, adalah 51-75. Range nilai untuk kategori sangat baik, adalah 76-100. 


\subsubsection{Uji Perspektif}

Uji perspektif merupakan pengujian yang dilakukan untuk mengetahui hasil yang terlihat dari pandangan mata. Uji perspektif dilakukan dari dua sisi, yaitu perspektif diri sendiri dan perspektif orang lain. Uji perspektif dilakukan untuk melihat kesesuaian hasil deteksi aplikasi dengan perspektif atau penilaian secara langsung dari diri sendiri dan dari orang lain. Untuk uji perspektif dari orang lain, digunakan 6 penilaian dari 6 orang yang berbeda untuk 1 koresponden.

\subsubsection{Kuisioner}

Pengujian menggunakan kuisioner merupakan salah satu cara untuk mengetahui kepuasan pengguna secara subjektif. Pada pengujian ini, responden diberikan 5 pertanyaan terkait aplikasi Try-On Hairstyle yang diikuti dengan 5 buah pilihan, yaitu Sangat Setuju (SS), Setuju (S), Cukup Setuju (CS), Kurang Setuju (KS), dan Tidak Setuju (TS). Berdasarkan data hasil kuisioner, dapat dicari persentase dari setiap penilaian dengan menggunakan Persamaan 1, yaitu [18]:

$$
Y=\frac{P}{Q} \times 100 \%
$$

di mana $Y$ merupakan hasil penilaian dari koresponden dalam persentase, $P$ merupakan banyaknya jawaban responden setiap soal, dan $Q$ merupakan total jumlah responden.

\section{Hasil Pengujian Sistem}

Pengujian sistem dilakukan untuk mengetahui apakah perangkat lunak yang dirancang telah memenuhi kriteria dan sesuai dengan tujuan perancangan perangkat lunak tersebut. Adapun parameter pengujian yang digunakan dalam penelitian ini adalah pengujian black box, pengujian berdasarkan jarak, pengujian berdasarkan intensitas cahaya, pengujian berdasarkan rotasi kepala, dan pengujian user acceptance.

\subsection{Hasil Pengujian Black Box}

Pengujian black box merupakan pengujian secara fungsionalitas dari setiap tampilkan pada aplikasi Try-On Hairstyle. Berikut merupakan hasil pengujian black box dari setiap item yang diuji:

1. Pengujian Halaman Utama

Pada halaman utama, terdapat judul aplikasi, tombol start, dan tombol exit. Tombol start berfungsi untuk memulai aplikasi, yaitu beralih ke halaman kamera. Tombol exit berfungsi untuk keluar dari aplikasi. Tabel 1 menampilkan skenario pengujian black box pada halaman utama aplikasi Try-On Hairstyle.

Tabel 1. Hasil pengujian halaman utama

\begin{tabular}{|c|c|c|}
\hline Skenario Pengujian & Pengamatan & Hasil Uji \\
\hline Uji tombol start & Berhasil masuk ke halaman kamera & Berhasil \\
\hline Uji tombol exit & Berhasil keluar dari aplikasi & Berhasil \\
\hline
\end{tabular}

2. Pengujian Halaman Kamera

Tampilan kamera berfungsi untuk menampilkan hasil pengenalan wajah dan pendeteksian wajah. Pada halaman kamera, terdapat tampilan kamera, tombol back, tombol play, tombol pause, tombol change camera, tombol exit, tombol man, dan tombol 
woman. Gambar 7 merupakan tampilan halaman kamera untuk mendeteksi wajah pada aplikasi Try-On Hairstyle.

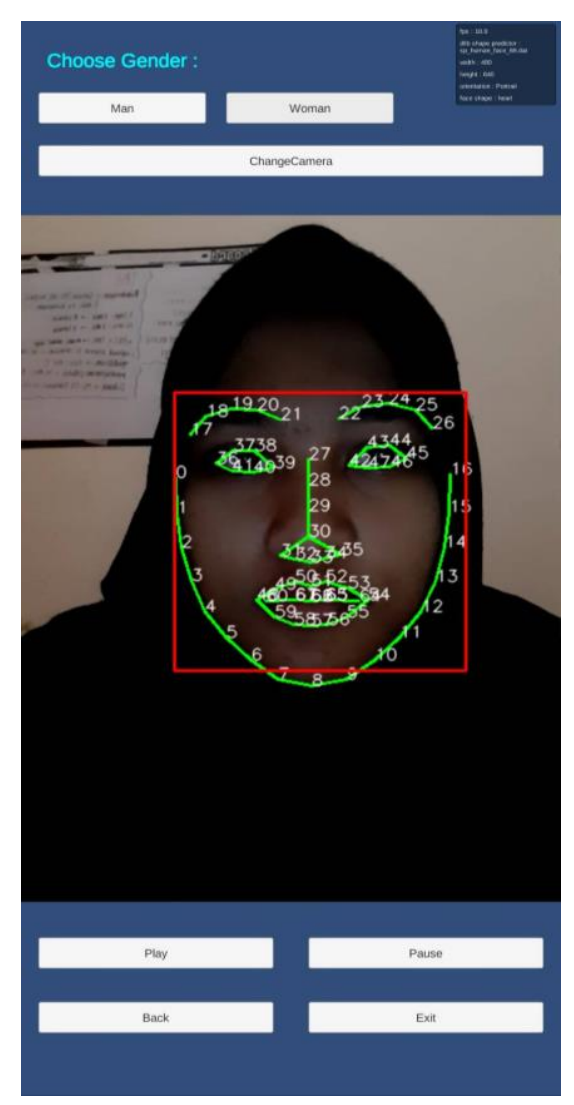

Gambar 7. Tampilan halaman kamera

Tombol back berfungsi untuk kembali ke halaman utama. Tombol play berfungsi untuk memulai kembali pendeteksian apabila pendeteksian dihentikan sementara. Tombol pause berfungsi untuk menghentikan sementara pendeteksian wajah. Tombol change camera berfungsi untuk mengganti kamera yang digunakan, menjadi kamera depan ataupun menjadi kamera belakang. Tombol exit berfungsi untuk keluar dari aplikasi. Tombol man berfungsi untuk menampilkan model rambut pria yang sesuai dengan bentuk wajah yang dihasilkan, lalu beralih ke halaman kamera AR. Tombol woman berfungsi untuk menampilkan model rambut wanita yang sesuai dengan bentuk wajah yang dihasilkan, lalu beralih ke halaman kamera AR. Tabel 2 menampilkan skenario pengujian black box pada halaman kamera aplikasi Try-On Hairstyle.

Tabel 2. Hasil pengujian halaman kamera

\begin{tabular}{|c|c|c|}
\hline Skenario Pengujian & Pengamatan & Hasil Uji \\
\hline Pendeteksian wajah & Berhasil mendeteksi wajah pengguna & Berhasil \\
\hline Uji tombol back & Berhasil kembali ke halaman utama & Berhasil \\
\hline Uji tombol play & Berhasil memulai kembali saat pendeteksian di pause & Berhasil \\
\hline Uji tombol pause & Berhasil pause pendeteksian wajah & Berhasil \\
\hline Uji tombol change camera & Berhasil mengubah ke kamera depan atau belakang & Berhasil \\
\hline Uji tombol exit & Berhasil keluar dari aplikasi & Berhasil \\
\hline Uji tombol man & Berhasil masuk ke halaman kamera AR untuk model rambut pria & Berhasil \\
\hline Uji tombol woman & Berhasil masuk ke halaman kamera AR untuk model rambut wanita & Berhasil \\
\hline
\end{tabular}


3. Pengujian Kotak Deskripsi

Kotak deskripsi merupakan kotak pada halaman kamera yang berfungsi untuk menampilkan hasil pengkategorian bentuk wajah sesuai dengan hasil deteksi. Kotak deskripsi ini bekerja secara real-time. Gambar 8 merupakan bentuk kotak deskripsi pada aplikasi Try-On Hairstyle. Tabel 3 menampilkan skenario pengujian black box pada kotak deskripsi pada halaman kamera aplikasi Try-On Hairstyle.

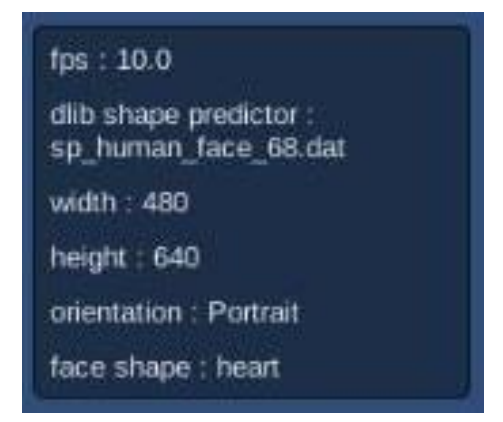

Gambar 8. Tampilan kotak deskripsi

Tabel 3. Hasil pengujian kotak deskripsi

\begin{tabular}{|c|c|c|}
\hline Skenario Pengujian & Pengamatan & Hasil Uji \\
\hline Menampilkan hasil deteksi bentuk wajah & Berhasil mengkategorikan sesuai bentuk wajah & Berhasil \\
\hline
\end{tabular}

4. Pengujian Halaman Kamera AR

Pada halaman kamera AR, terdapat tampilan kamera, tombol back, tombol play, tombol pause, tombol change camera, dan tombol exit. Tampilan kamera berfungsi untuk menampilkan hasil model rambut yang sesuai dengan kategori bentuk wajah yang terdeteksi pada halaman kamera. Pada aplikasi ini, terdapat 4 model rambut pria dan 5 model rambut wanita. Tombol back berfungsi untuk kembali ke halaman utama. Tombol play berfungsi untuk memulai kembali pendeteksian apabila pendeteksian dihentikan sementara. Tombol pause berfungsi untuk menghentikan sementara pendeteksian wajah. Tombol change camera berfungsi untuk mengganti kamera yang digunakan, menjadi kamera depan ataupun menjadi kamera belakang. Tombol exit berfungsi untuk keluar dari aplikasi. Gambar 9 merupakan gambar tampilan halaman kamera AR pada aplikasi Try-On Hairstyle. Sedangkan Tabel 4 menampilkan skenario pengujian black box pada halaman kamera AR aplikasi Try-On Hairstyle. 


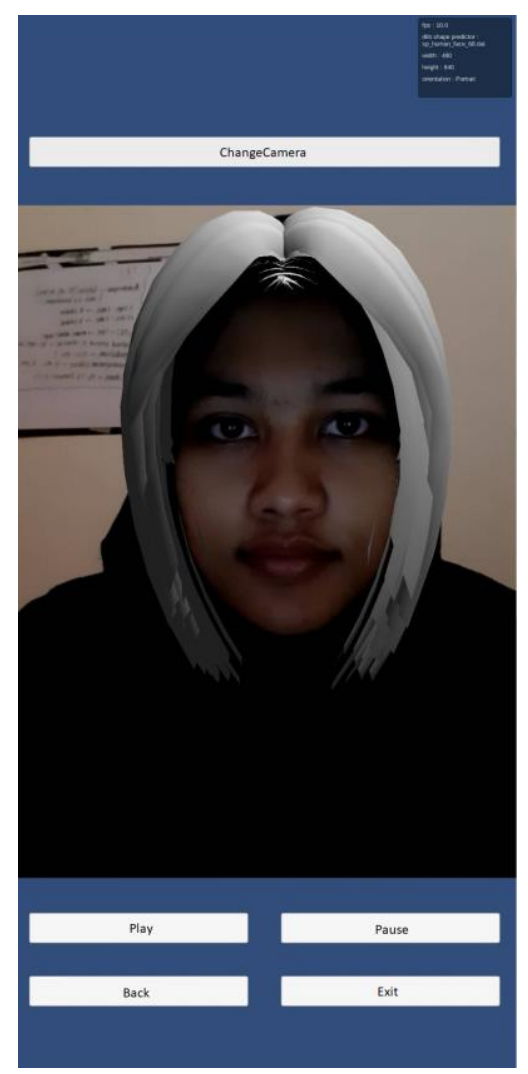

Gambar 9. Tampilan halaman kamera AR

Tabel 4. Hasil pengujian halaman kamera AR

\begin{tabular}{|c|c|c|}
\hline Skenario Pengujian & Pengamatan & Hasil Uji \\
\hline Menampilkan AR Rambut & Berhasil menampilkan bentuk rambut & Berhasil \\
\hline Uji tombol back & Berhasil kembali ke halaman utama & Berhasil \\
\hline Uji tombol play & Berhasil memulai kembali saat pendeteksian di pause & Berhasil \\
\hline Uji tombol pause & Berhasil pause pendeteksian wajah & Berhasil \\
\hline Uji tombol change camera & Berhasil mengubah ke kamera depan atau belakang & Berhasil \\
\hline Uji tombol exit & Berhasil keluar dari aplikasi & Berhasil \\
\hline
\end{tabular}

\subsection{Hasil Pengujian Berdasarkan Jarak}

Pengujian berdasakan jarak dilakukan untuk mengetahui jarak maksimum, jarak minimum, serta jarak terbaik wajah manusia terdeteksi oleh aplikasi. Pengujian ini dilakukan dengan jarak $10 \mathrm{~cm}$ sampai dengan $100 \mathrm{~cm}$ antara kamera depan ponsel dengan wajah pengguna. Wajah akan terdeteksi oleh sistem apabila sistem bisa membaca bentuk wajah beserta fitur-fitur lainnya secara sempurna. Tabel 5 merupakan hasil pengujian jarak.

Tabel 5. Hasil pengujian berdasarkan jarak

\begin{tabular}{|c|c|c|}
\hline Jarak & Hasil Uji & Akurasi (\%) \\
\hline $10-40 \mathrm{~cm}$ & Terdeteksi & 100 \\
\hline $50-70 \mathrm{~cm}$ & Terdeteksi & 100 \\
\hline $80-100 \mathrm{~cm}$ & Terdeteksi & 100 \\
\hline
\end{tabular}

Berdasarkan hasil pengujian pada jarak $10 \mathrm{~cm}$ hingga $100 \mathrm{~cm}$ terhadap kamera depan ponsel, sistem dapat mendeteksi bagian wajah dengan baik. Oleh karena itu, diperoleh akurasi $100 \%$ pada pengujian jarak $10-100 \mathrm{~cm}$. 


\subsection{Hasil Pengujian Berdasarkan Intensitas Cahaya}

Pengujian berdasarkan cahaya dilakukan untuk mengetahui intensitas maksimum cahaya dan intensitas minimum cahaya yang menyebabkan wajah dapat terdeteksi dengan aplikasi. Pengujian ini dilakukan dengan berbagai intensitas cahaya, yaitu intensitas cahaya sangat tinggi (24000 lux), tinggi (450 lux), sedang (150 lux), rendah (15 lux), dan sangat rendah (10 lux). Wajah akan terdeteksi apabila kamera depan ponsel dapat menampilkan wajah pengguna dengan sempurna dengan intensitas cahaya yang digunakan. Tabel 6 merupakan hasil pengujian berdasarkan intensitas cahaya.

Tabel 6. Hasil pengujian berdasarkan intensitas cahaya

\begin{tabular}{|c|c|c|}
\hline Intensitas Cahaya & Hasil Uji & Akurasi (\%) \\
\hline Sangat Tinggi (24000 lux) & Terdeteksi & 100 \\
\hline Tinggi (450 lux) & Terdeteksi & 100 \\
\hline Sedang (150 lux) & Terdeteksi & 100 \\
\hline Rendah (15 lux) & Terdeteksi & 100 \\
\hline Sangat Rendah (10 lux) & Tidak Terdeteksi & 0 \\
\hline
\end{tabular}

Berdasarkan hasil pengujian berdasarkan intensitas cahaya, pada intensitas cahaya rendah, yaitu 15 lux, sampai sangat tinggi, yaitu 24000 lux, wajah masih bisa terdeteksi dengan baik oleh sistem. Sehingga, diperoleh akurasi $100 \%$ pada pengujian intensitas cahaya 15 - 24000 lux. Sedangkan, pada intensitas cahaya sangat rendah, yaitu 10 lux, wajah sudah tidak bisa terdeteksi oleh sistem.

\subsection{Hasil Pengujian Berdasarkan Rotasi Kepala}

Pengujian berdasarkan rotasi kepala dilakukan untuk mengetahui derajat maksimum dan derajat minimum rotasi kepala yang menyebabkan wajah dapat terdeteksi dengan aplikasi. Pengujian dilakukan dengan uji deteksi wajah pengguna dengan kamera depan ponsel dengan rotasi kepala $0^{\circ}-90^{\circ}$. Sudut $0^{\circ}$ merupakan sudut wajah frontal dengan kamera. Wajah akan terdeteksi oleh sistem apabila sistem bisa membaca bentuk wajah beserta fitur-fitur lainnya secara sempurna. Tabel 7 menampilkan hasil pengujian berdasarkan rotasi kepala.

Tabel 7. Hasil pengujian berdasarkan rotasi kepala

\begin{tabular}{|c|c|c|}
\hline Rotasi Kepala & Hasil Uji & Akurasi (\%) \\
\hline $0^{\circ}$ & Terdeteksi & 100 \\
\hline $30^{\circ}$ & Terdeteksi & 100 \\
\hline $45^{\circ}$ & Terdeteksi & 100 \\
\hline $60^{\circ}$ & Tidak Terdeteksi & 0 \\
\hline $90^{\circ}$ & Tidak Terdeteksi & 0 \\
\hline
\end{tabular}

Berdasarkan hasil pengujian berdasarkan rotasi kepala, sistem masih bisa mendeteksi wajah dengan baik hingga sudut $45^{\circ}$. Sehingga, diperoleh akurasi $100 \%$ pada pengujian berdasarkan rotasi kepala $0^{\circ}-45^{\circ}$. Sedangkan, apabila posisi kepala terhadap kamera depan ponsel lebih dari $45^{\circ}$, sistem sudah tidak bisa mendeteksi wajah dengan baik.

\subsection{Hasil Pengujian User Acceptance}

\subsubsection{Hasil Pengujian Berdasarkan Uji Coba Langsung}

Uji coba kepada pengguna secara langsung terhadap aplikasi dilakukan agar dapat mengetahui tingkat kepuasan pengguna terhadap aplikasi tersebut. Parameter yang menjadi patokan untuk uji coba secara langsung adalah tampilan aplikasi, fungsionalitas 
aplikasi, hasil yang ditampilkan oleh aplikasi, dan tingkat kepuasan pengguna. Range nilai untuk setiap parameternya adalah 1 hingga 100. Terdapat 4 kategori penilaian, yaitu kurang, cukup, baik, dan sangat baik.

Berdasarkan hasil uji coba secara langsung kepada 10 pria dan 10 wanita, didapatkan nilai rata-rata uji coba secara langsung sebesar $91,7625 \%$. Hasil rata-rata setiap parameter dihitung dan menghasilkan nilai rata-rata dari parameter tampilan sebesar 91,5\%, nilai rata-rata dari parameter fungsionalitas sebesar $91,2 \%$, nilai rata-rata dari parameter hasil yang ditampilkan sebesar $91,15 \%$, dan nilai rata-rata dari parameter tingkat kepuasan pengguna sebesat $93,2 \%$.

\subsubsection{Hasil Pengujian Berdasarkan Uji Perspektif}

Uji perspektif merupakan pengujian yang dilakukan untuk mengetahui hasil yang terlihat dari pandangan mata. Uji perspektif ini dilakukan dari dua sisi, yaitu perspektif pribadi dan perspektif orang lain. Uji perspektif dilakukan dengan cara survey langsung kepada pengguna dan orang-orang disekitar pengguna. Uji perspektif dilakukan kepada 10 koresponden pria dan 10 koresponden wanita dengan 6 perspektif orang lain dari setiap koresponden.

Berdasarkan hasil perbandingan antara hasil pengujian berdasarkan rata-rata dari perspektif orang lain dengan hasil deteksi aplikasi, hasil akurasi yang diperoleh adalah $80 \%$ atau 16 dari 20 koresponden yang hasil deteksi dengan aplikasi sesuai dengan ratarata perspektif dari orang lain. Ketidaksesuaian tersebut dapat disebabkan oleh berbagai hal, seperti sudut wajah yang tidak pas pada saat pendeteksian dan perbedaan perspektif terhadap 7 bentuk wajah manusia yang menjadi patokan dalam penelitian ini.

\subsubsection{Hasil Pengujian Berdasarkan Kuisioner}

Pengujian aplikasi dengan kuisioner dilakukan untuk memberikan hasil persentasi dari kepuasan pengguna selain dari uji coba secara langsung. Dari hasil kuesioner tersebut, kemudian dilakukan perhitungan persentase dari setiap poin jawaban dari setiap pertanyaan menggunakan (1) untuk dapat diambil kesimpulan terhadap penilaian penerapan sistem aplikasi. Untuk pertanyaan yang diajukan kepada koresponden adalah sebagai berikut:

1. Apakah anda setuju bahwa aplikasi Try-On Hairstyle dapat melakukan pemilihan model rambut yang sesuai dengan bentuk wajah?

2. Apakah anda setuju aplikasi aplikasi Try-On Hairstyle memudahkan pengguna dalam menentukan model rambut?

3. Apakah anda setuju tampilan dari aplikasi Try-On Hairstyle menarik?

4. Apakah anda setuju aplikasi Try-On Hairstyle berfungsi dengan baik?

5. Apakah anda setuju aplikasi Try-On Hairstyle memberikan hasil sesuai dengan yang diharapkan?

Untuk penilaian, digunakan 5 indeks sebagai acuan, yaitu sangat setuju (SS), setuju (S), cukup setuju (CS), kurang setuju (KS), dan tidak setuju (TS). Tabel 8 menampilkan data hasil kuisioner. Gambar 10 menampilkan persentase jawaban setiap pertanyaan dengan kategori baik. 
Tabel 8. Data hasil kuisioner

\begin{tabular}{|c|c|c|c|c|c|}
\hline Pertanyaan & SS & S & CS & KS & TS \\
\hline 1 & 9 & 11 & 0 & 0 & 0 \\
\hline 2 & 10 & 9 & 1 & 0 & 0 \\
\hline 3 & 12 & 6 & 2 & 0 & 0 \\
\hline 4 & 11 & 8 & 1 & 0 & 0 \\
\hline 5 & 8 & 10 & 2 & 0 & 0 \\
\hline
\end{tabular}

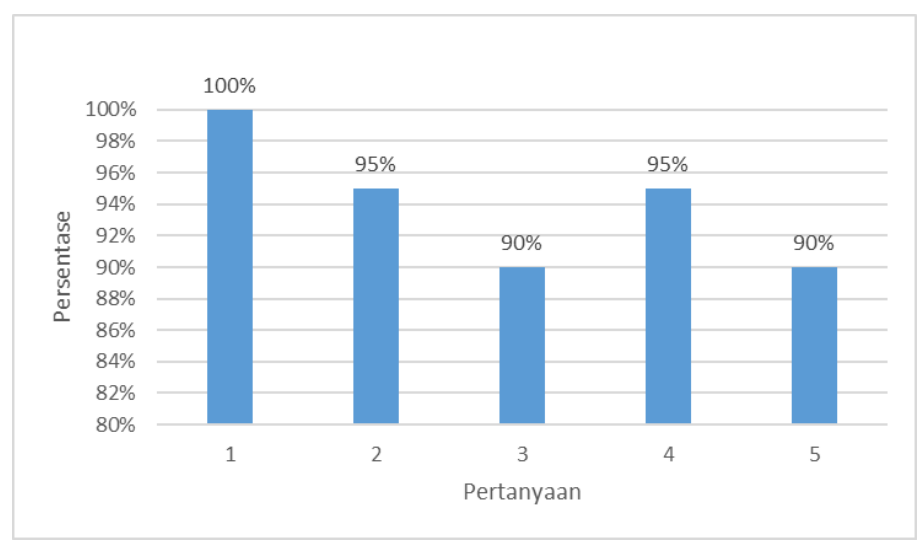

Gambar 5. Persentase jawaban dengan kategori baik

Berdasarkan hasil pengujian dengan kuisioner oleh 20 responden, yang ditampilkan pada Tabel 8 dan Gambar 10, dapat disimpulkan bahwa seluruh koresponden atau 100\% setuju dengan digunakannya teknologi Augmented Reality untuk aplikasi Try-On Hairstyle, 95\% setuju dengan aplikasi Try-On Hairstyle mempermudah pengguna dalam menentukan model rambut, 90\% setuju dengan tampilan aplikasi yang menarik, 95\% setuju dengan fungsi aplikasi yang berfungsi dengan baik, dan $90 \%$ setuju dengan aplikasi ini memberikan hasil sesuai dengan yang diharapkan oleh pengguna.

\section{Kesimpulan}

Pada penelitian ini telah dirancang aplikasi Try-On Hairstyle berbasis Android dengan metode Viola-Jones dan teknologi Augmented Reality. Aplikasi Try-On Hairstyle ini dapat mengkategorikan bentuk wajah dan dapat menampilkan rekomendasi model rambut berdasarkan kategori bentuk wajah pria atau wanita. Sistem aplikasi Try-On Hairstyle bekerja dengan baik dengan tingkat akurasi $100 \%$. Berdasarkan pengujian user acceptance, tingkat kelayakan dan kepuasan pengguna terhadap aplikasi Try-On Hairstyle ini adalah 91,7625\%.

Parameter yang digunakan dalam pengujian ini adalah jarak, intensitas cahaya, dan rotasi kepala atau sudut wajah terhadap kamera. Pengujian berdasarkan jarak menghasilkan akurasi sebesar $100 \%$ dengan uji jarak $10 \mathrm{~cm}-100 \mathrm{~cm}$, dengan jarak terbaik yang menghasilkan hasil deteksi wajah yang optimal adalah pada jarak $30 \mathrm{~cm}-40 \mathrm{~cm}$. Pengujian berdasarkan intensitas cahaya menghasilkan akurasi sebesar $100 \%$ dengan intensitas cahaya yang dapat terdeteksi $>10$ lux. Pengujian berdasarkan rotasi kepala atau sudut wajah terhadap kamera menghasilkan akurasi $100 \%$ dengan keadaan sudut wajah $0^{\circ}-45^{\circ}$ terhadap kamera, dengan $0^{\circ}$ merupakan sudut wajah terhadap kamera yang menghasilkan hasil deteksi terbaik. 


\section{Daftar Pustaka}

[1] R. Aggarwal and A. Singhal, "Augmented Reality and Its Effect on Our Life," Proc. 9th Int. Conf. Cloud Comput. Data Sci. Eng. Conflu. 2019, pp. 510-515, 2019, doi: 10.1109/CONFLUENCE.2019.8776989.

[2] I. Mustaqim and N. Kurniawan, "Pengembangan Media Pembelajaran Pai Berbasis Augmented Reality," J. Edukasi Elektro, vol. 1, no. 1, pp. 36-48, 2017, doi: 10.24252/lp.2018v21n1i6.

[3] M. Muntahanah, R. Toyib, and M. Ansyori, "Penerapan Teknologi Augmented Reality Pada Katalog Rumah Berbasis Android (Studi Kasus Pt. Jashando Han Saputra)," Pseudocode, vol. 4, no. 1, pp. 81-89, 2017, doi: 10.33369/pseudocode.4.1.81-89.

[4] F. Lenurra and D. Pratiwi, "Penerapan Teknologi Augmented Reality Sebagai Media Promosi Apartemen Dengan Metode Markerless," Semin. Nas. Cendikiawan, vol. 3, pp. 77-83, October 2017, [Online]. Available: https://www.trijurnal.lemlit.trisakti.ac.id/semnas/article/view/2167/1849.

[5] Y. Indrawaty, U. Ungkawa, and D. Sofia, Pengembangan Aplikasi Simulasi Model Rambut Menggunakan Augmented Reality. Bandung: Institut Teknologi Nasional Bandung, 2018.

[6] P. A. T. R. Karda, I. M. A. Suyadnya, and D. C. Khrisne, "Rancang Bangun Aplikasi Augmented Reality Sebagai Media Promosi Model Tatanan Rambut Pada Barbershop Berbasis Android," SINTECH (Science Inf. Technol. J., vol. 1, no. 1, pp. 16-24, 2018, doi: 10.31598/sintechjournal.v1i1.226.

[7] C. Philippe, "What Is My Face Shape? A Gentleman's Guide To Find It In 5 Easy Steps," Bespoke Unit, 2018. https://bespokeunit.com/face-shapes/identifying/ (accessed Jun. 22, 2020).

[8] Headcurve, "9 Face Shapes for Women and Best Hairstyles for Each," Headcurve, 2019. https://www.headcurve.com/hair/rose-byrne/ (accessed Jun. 22, 2020).

[9] Akanksha, J. Kaur, and H. Singh, "Face detection and Recognition : A Review," in 6th International Conference on Advancements in Engineering \& Technology (ICAET2018), 2018, pp. 138-140.

[10] Sightcorp, "Face Tracking," Sightcorp. https://sightcorp.com/knowledge-base/facetracking/ (accessed Jun. 22, 2020).

[11] A. R. Syafira and G. Ariyanto, "Sistem Deteksi Wajah Dengan Modifikasi Metode Viola Jones," Emit. J. Tek. Elektro, vol. 17, no. 1, pp. 26-33, 2017, doi: 10.23917/emitor.v17i1.5964.

[12] Arman Basir, "Algoritma Viola Jones," TutorialsWB, 2017. https://www.tutorialswb.com/2017/07/algoritma-viola-jones.html (accessed Jun. 22, 2020).

[13] Hanugra Aulia Sidharta, "Introduction to Open CV," Binus University, 2017. https://binus.ac.id/malang/2017/10/introduction-to-open-cv/ (accessed Jun. 22, 2020).

[14] H. Kusumo, Analisis Dan Implementasi Face Detection Menggunakan Metode Viola Jones. Bandung: Institut Teknologi Telkom, 2010.

[15] T. A. Kurniawan, "Pemodelan Use Case (UML): Evaluasi Terhadap beberapa Kesalahan dalam Praktik," J. Teknol. Inf. dan Ilmu Komput., vol. 5, no. 1, p. 77, 2018, doi: 10.25126/jtiik.201851610. 
[16] P. D. Wananda, L. Novamizanti, R. D. Atmaja, Sistem Deteksi Cacat Kayu dengan Metode Deteksi Tepi SUSAN dan Ekstraksi Ciri Statistik, ELKOMIKA: Jurnal Teknik Energi Elektrik, Teknik Telekomunikasi \& Elektronika, vol 6, no 1, 2018.

[17] M. S. Ramadhan, L. Novamizanti, E. Susatio, Sistem Pengenalan Individu Berbasis Citra Wajah 3D dengan Jaringan Syaraf Tiruan. Techné: Jurnal Ilmiah Elektroteknika vol. 18, no. 01, pp. 1-14, 2019.

[18] R. A. Nabawi, Aplikasi Augmented Reality untuk Memilih Model Rambut di Headcore Barbershop Dengan Metode Face Recognition Sebagai Pendeteksi Marker. Bandung: Universitas Komputer Indonesia, 2012. 